\title{
Incidence of Mild Cognitive Impairment: A Systematic Review
}

\author{
Tobias Luck $^{a}$ Melanie Luppa ${ }^{a}$ Susanne Briel ${ }^{a}$ Steffi G. Riedel-Heller ${ }^{a}$ b \\ a Public Health Research Unit, Department of Psychiatry and Psychotherapy, Department of Mental Health, and \\ ${ }^{b}$ Department of Social Medicine, University of Leipzig, Leipzig, Germany
}

\section{Key Words}

Mild cognitive impairment, incidence $\cdot$ Review, mild cognitive impairment $\cdot$ Risk factor, dementia . Epidemiology

\begin{abstract}
Background/Aims: Subjects with mild cognitive impairment $(\mathrm{MCl})$ constitute a risk population of developing dementia and thus a population of clinical interest. This study reviews recent work on the incidence of $\mathrm{MCl}$ in the elderly. Methods: Incidence papers were identified by a systematic literature search. Studies on the incidence of $\mathrm{MCl}$ were considered if they identified 'cognitively mildly impaired' subjects by application of the $\mathrm{MCl}$ criteria, used the 'personyears-at-risk' method, and were based on population- or community-based samples. Results: Nine studies were identified. The incidence of amnestic $\mathrm{MCl}$ subtypes ranged between 9.9 and 40.6 per 1,000 person-years, and the incidence of non-amnestic MCl subtypes was 28 and 36.3 per 1,000 person-years. Regarding any $\mathrm{MCl}$, incidence rates of 51 and 76.8 per 1,000 person-years were found. A higher risk of incident $\mathrm{MCl}$ mainly resulted for higher age, lower education and hypertension. Discussion: The incidence rates of $\mathrm{MCl}$ varied widely, and possible risk factors for incident $\mathrm{MCl}$ were analysed only to a limited extent. The findings call for an agreement concerning the criteria used for $\mathrm{MCl}$ and the operationalisation of these criteria.
\end{abstract}

Copyright $\odot 2010$ S. Karger AG, Basel

\section{KARGER}

Fax +4161306 1234 E-Mail karger@karger.ch www.karger.com
(C) 2010 S. Karger AG, Base

$1420-8008 / 10 / 0292-0164 \$ 26.00 / 0$

Accessible online at:

www.karger.com/dem

\section{Introduction}

Dementia is not only one of the most burdensome diseases for sufferers and their caregivers, it is also one of the biggest challenges for developed countries and their health care systems. Based on 24.3 million dementia sufferers in the year 2001, Ferri et al. [1] estimated a worldwide increase of 4.6 million new dementia cases every year. Without changes in mortality and new effective prevention strategies or curative treatments, the number of affected people will double every 20 years to 81.1 million by 2040. Dementia - particularly of the Alzheimer's type - is normally preceded by a period of mild cognitive impairments (MCI). Several concepts, like age-associated memory impairment [2], aging-associated cognitive decline [3] or cognitively impaired, not demented $[4,5]$ have been used in the past in order to define those mild impairments. Today, especially the concept of MCI [6-9] has become increasingly popular in clinical research and practice $[10,11]$. Several studies [12-15] have shown that elderly individuals with MCI constitute a high-risk population of developing dementia. MCI - compared to most of the other concepts - has always been defined in order to characterise an abnormal clinical state, prodromal to dementia [10]. The prodromal state of MCI has been demonstrated with regard to neuropathological substrates (e.g. neuritic plaques, neurofibrillary tangles, hippocampal atrophy) in numerous studies $[10,16,17]$.

Dr. rer. med. Tobias Luck, Dipl.-Psych.

Public Health Research Unit, Department of Psychiatry and Psychotherapy,

Department of Mental Health, University of Leipzig

Semmelweisstrasse 10, DE-04103 Leipzig (Germany)

Tel. +49341972 4568, Fax +49 341972 4539, E-Mail tobias.luck@ medizin.uni-leipzig.de 
In order to assess the possible need for secondary prevention and care as well as to explore preventive approaches for MCI leading to dementia, reliable data on the epidemiology are required. Many existing epidemiological studies on MCI are mainly based on prevalent cases [e.g. 13, 18-23]. Studies based on incident MCI cases provide the opportunity to look at cognitively impaired subjects from the onset of their impairment. This allows precise statements concerning the course of the impairment by including a prospective analysis of possible risk factors. To the best of our knowledge, there is no existing systematic review of results on the incidence of MCI in the international literature. Thus, we aimed to systematically review all published population- or communitybased studies analysing the incidence of MCI with the following objectives: (i) describing characteristics of the studies (country, sample, observation interval, MCI criteria and their operationalisation, etc.); (ii) comparing findings on MCI incidence rates in consideration of the study characteristics and identified risk factors, and (iii) summarising current research findings and drawing conclusions for future research in this area.

\section{Methods}

\section{Definition of $\mathrm{MCI}$}

During the last few years, the MCI concept has continuously been further developed, and studies have often additionally modified original criteria. General criteria of the different definitions of the MCI concept [6-9], however, are rather identical and usually comprise: (1) a cognitive complaint (self-reported and/or informant); (2) preserved basic activities of daily living; (3) cognitive impairment (not normal for age and education) or decline in cognition evidenced by performance on objective cognitive tasks; (4) preserved general cognitive functioning (not required in $[6,9]$ ), and (5) absence of dementia.

Discrepancies between the different definitions of the MCI concept mainly consist of the number and type of the impaired cognitive domains. Primarily, the MCI concept only requires impairment in memory with preserved general cognitive functioning at the same time [8]. Today, MCI can be divided into 4 subtypes $[6,9]$.

- Amnestic MCI single domain: objective impairment in memory but not in another cognitive domain.

- Amnestic MCI multiple domain: objective impairment in memory and in at least 1 other cognitive domain.

- Non-amnestic MCI single domain: objective impairment in a single cognitive domain other than memory.

- Non-amnestic MCI multiple domain: objective impairment in at least 2 cognitive domains other than memory.

Systematic Literature Search

Relevant publications on the incidence of MCI were identified by searching the electronic databases Medline, Web of Science,
Cochrane Library and Psychinfo as well as bibliographies of several articles. 'Mild cognitive impairment', 'MCI' and 'incidence' served as keywords. The following selection criteria were applied: (i) application of the MCI criteria [6-9] in order to identify 'cognitively mildly impaired' subjects; (ii) studies considering the incidence of MCI as outcome criteria using the 'person-years-atrisk' method ${ }^{1}$; (iii) studies with population- or community-based samples, and (iv) studies in English or German. Because the first MCI criteria [8] had already been used in some previous studies [24], the systematic literature search comprised the time period between January 1995 and September 2009.

\section{Results}

The results of the systematic literature search are presented in figure 1. Altogether, 9 studies on the incidence of MCI fulfilling the specified selection criteria were found.

Tables 1 and 2 provide an overview of the studies. Six of the 9 studies were conducted in Europe, 2 in the USA and 1 in Brazil. European studies were related to population-based samples and American and Brazilian studies to community-based samples. The population at risk for incident $\mathrm{MCI}$ ranged between 245 and 1,800 subjects. In the majority of the studies, the age of the participants at baseline was at least 65 or 75 years. Younger participants ( $\geq 60$ years) were only included in the studies by Tervo et al. [25] and Chaves et al. [26]. The observation intervals for incident MCI ranged between 3 and 9 years and the number of follow-ups between 1 and 3 .

Regarding MCI subtypes, information on the incidence of amnestic MCI single domain was given in 2 studies $[28,30]$ and on the incidence of amnestic MCI multiple domain, non-amnestic MCI single domain and non-amnestic MCI multiple domain in 1 study [28]. Eight studies $[21,22,25-29,31]$ provided information on the incidence of the amnestic MCI subtypes combined (single + multiple domain) and $2[21,28]$ on the incidence of the non-amnestic MCI subtypes combined. Information on the incidence of any MCI (all 4 subtypes combined) was also given in 2 studies [21,28].

As shown in table 1, 4 of the 9 studies have modified original MCI criteria; 3 reports provide information on incidence of MCI omitting the criterion of cognitive complaint $[21,22,30]$ and 1 study omitting the criteria of cognitive complaint and preserved basic activities of daily living [25]. Studies also differ in the operationalisation of

\footnotetext{
1 Incidence is calculated as the number of new MCI cases divided by the time at risk of developing MCI (person-years).
} 
Table 1. Studies on incidence of MCI

\begin{tabular}{|c|c|c|c|c|c|}
\hline \multirow[t]{2}{*}{ Study } & \multirow{2}{*}{$\begin{array}{l}\text { MCI subtypes/ } \\
\text { underlying } \\
\text { definition of MCI }\end{array}$} & \multicolumn{4}{|l|}{ MCI criteria } \\
\hline & & cognitive complaint & $\begin{array}{l}\text { preserved basic activities of } \\
\text { daily living }\end{array}$ & cognitive impairment & $\begin{array}{l}\text { exclusion of } \\
\text { dementia }\end{array}$ \\
\hline $\begin{array}{l}\text { Chaves et al. } \\
(2009)[26] \\
\text { Brazil }\end{array}$ & $\begin{array}{l}\text { aMCI-SD/MD- } \\
\text { combined }^{1} \\
\text { Petersen et al. [24] }\end{array}$ & $\begin{array}{l}\text { Memory complaint; } \\
\text { reported by participant, } \\
\text { family, physician }\end{array}$ & $\begin{array}{l}\text { No impairment on Katz ADL } \\
\text { scale }\end{array}$ & $\begin{array}{l}\text { Memory impairment: test scores }>1.5 \\
\text { standard deviations below age- } \\
\text { appropriate norms or abnormal } \\
\text { memory function for age; tests n.s. } \\
\text { Preserved general cognitive } \\
\text { functioning: n.s. } \\
\text { CDR global score }=0.5\end{array}$ & $\begin{array}{l}\text { DSM-IV criteria for } \\
\text { dementia, } \\
\text { NINCDS-ADRDA } \\
\text { criteria for AD }\end{array}$ \\
\hline
\end{tabular}

\begin{tabular}{lll}
\hline Caracciolo et al. & aMCI-SD/MD- & Memory complaint; \\
(2008) [27], & combined $^{1}$ & $\begin{array}{l}\text { reported by } \\
\text { Kungsholmen }\end{array}$ \\
Petersen et al. [8] & $\begin{array}{l}\text { participants, close } \\
\text { informant or both }\end{array}$ \\
Project, & & Sweden
\end{tabular}
No impairment on Katz ADL scale or slight functional impairment (judged by an examining physician to not be attributable to cognitive impairment)

\section{Memory impairment: test performance \\ $<1.5$ standard deviations below the mean \\ of age- and education-specific norms on a verbal memory task (free recall) \\ Preserved general cognitive functioning: test performance not $<1$ standard deviation below age- and education- specific means on the MMSE}

\begin{tabular}{|c|c|c|c|}
\hline $\begin{array}{l}\text { Manly et al. } \\
(2008)[28] \\
\text { USA }\end{array}$ & $\begin{array}{l}\text { (1) aMCI-SD } \\
\text { (2) aMCI-MD } \\
\text { (3) aMCI-SD/MD- } \\
\text { combined } \\
\text { (4) naMCI-SD } \\
\text { 4a: executive } \\
\text { 4b: language } \\
\text { 4c: visuospatial } \\
\text { (5) naMCI-MD } \\
\text { (6) naMCI-SD/MD- } \\
\text { combined } \\
\text { (7) any MCI } \\
\text { Petersen [6], } \\
\text { Petersen et al. [7] }\end{array}$ & $\begin{array}{l}\text { No indication of } \\
\text { memory problems on } \\
\text { the DFL and BFA scales }\end{array}$ & $\begin{array}{l}\text { Reported by participants or } \\
\text { caregivers; assessed by the DFI } \\
\text { scale for IADLs }\end{array}$ \\
\hline
\end{tabular}

Ravaglia et al. (1) aMCI-SD/MD- The criterion has been (2008) [21], combined omitted

CSBA, Italy

(2) naMCI-SD/MD-

combined

(3) any MCI

Winblad et al. [9]

Cognitive impairment: test performance

in at least 1 cognitive domain $<1.5$ standard deviations below the mean, corrections for age, education, ethnicity, and sex based on previously established norms; assessed by SRT and BVRT for memory; LF, CF and WAIS-Revised Similarities subtest for executive function; $\mathrm{BNT}$ and $\mathrm{BDAE}$ for language; RDT and BVRT matching for visualspatial ability

Preserved general cognitive functioning: for MCI subtypes with isolated impairment in 1 cognitive domain (aMCI SD, naMCI SD), no impairment (test performance not $<1.5$ standard deviations below the mean, corrections for age, education, ethnicity and sex based on previously established norms) in other cognitive domains

Cognitive impairment: age- and education-adjusted test scores 1.5 standard deviations or fewer below the reference thresholds in at least 1 cognitive domain; assessed by PMT for memory and MDB for memory, language, frontal function, abstract reasoning and visuospatial abilities Preserved general cognitive functioning: not required

\begin{tabular}{lll}
\hline Verghese et al. & aMCI-SD/MD- & $\begin{array}{l}\text { Memory complaint; } \\
\text { reported by }\end{array}$ \\
(2006) [29], & combined $^{1}$ & $\begin{array}{l}\text { participants, informant } \\
\text { report when available }\end{array}$ \\
Study, USA & Petersen et al. [8] &
\end{tabular}

No need for supervision or external help to perform any IADL Scale; no exclusion of subjects with functiona dependency due to physical impairment ADL (Katz ADL Scale) or
DSM-III-R criteria

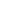

DSM-III-R criteria for dementia, NINCDS-ADRDA criteria for AD and NINDS-AIREN criteria for VD and consortium on DLB international workshop criteria for DLB; CDR for severity rating
Memory impairment: 3 or more errors on the 5-item Blessed test memory phrase (corresponds to performance at or below 1.5 standard deviations below the mean)

Preserved general cognitive functioning: verbal IQ (WAIS) score not $<1$ standard deviation below the population mean and a score of $<8$ on the Blessed test

\author{
DSM-III-R criteria, \\ NINCDS-ADRDA \\ criteria for $\mathrm{AD}$ and \\ ADRCC criteria for \\ VD \\ (n)
}

DSM-IV criteria for dementia, NINCDS-

ADRDA criteria fo

AIREN criteria for

VD 


\begin{tabular}{lllll}
\hline Sample & $\begin{array}{l}\text { OI (years)/ } \\
\text { No. of } \\
\text { FUPs }\end{array}$ & $\begin{array}{l}\text { Age at } \\
\text { baseline } \\
\text { years }\end{array}$ & $\begin{array}{l}\text { Population } \\
\text { at risk for } \\
\text { incident MCI }\end{array}$ & $\begin{array}{l}\text { Incident } \\
\text { MCI cases } \\
\%(\mathrm{n})\end{array}$ \\
\hline community-based & $8 /$ n.s. & $60+$ & $245^{2}$ & $7.3^{3}(18)$
\end{tabular}

community-based

$60+$

$245^{2}$

$7.3^{3}(18)$

$13.2(7.79-20.91)$

$\begin{array}{llllll}\text { population-based } & 9 / 3 & 75+ & 1,070 & 6.0^{3}(64)\end{array}$

community-based (multiethnic community: Caribbean Hispanic,

black and non-Hispanic white

people) mean $=4.7$
$(\mathrm{SD}=2.8)$

mean $=2.3$
$65+$

1,800

(1) $5.8^{3}(105)$

(2) $3.6^{3}(65)$

(3) $9.4^{3}(170)$

(4a) $1.1^{3}(19)$

(4b) $3.7^{3}(67)$

(4c) $4.7^{3}(85)$

(4) $9.5^{3}(171)$

(5) $2.1^{3}(38)$

(6) $11.6^{3}(209)$

(7) $21.1^{3}(379)$

\section{(1) 14 (11-17)}

(2) $9(7-11)$

(3) $23(19-26)$

(4a) $3(1-4)$

(4b) $9(7-11)$

(4c) $11(9-14)$

(4) $23^{5}$

(5) $5(1-7)$

(6) $28(24-32)$

(7) $51(46-56)$

population-based

mean $=3.8$

$(\mathrm{SD}=0.8) / 1$

$65+$

685

(1) 11.5 (79)

$40.6(33.5-49.2)$

(3) $22.6(155)$

$76.8(66.8-88)$

community-based mean $=5.6$

$(\mathrm{SD}=4.1) /$

FUPs every

12-18 months 
Table 1 (continued)

\begin{tabular}{|c|c|c|c|c|}
\hline \multirow[t]{2}{*}{ Study } & \multirow{2}{*}{$\begin{array}{l}\text { MCI subtypes/ } \\
\text { underlying } \\
\text { definition of MCI }\end{array}$} & \multicolumn{3}{|l|}{ MCI criteria } \\
\hline & & cognitive complaint & $\begin{array}{l}\text { preserved basic activities of } \\
\text { daily living }\end{array}$ & cognitive impairment \\
\hline $\begin{array}{l}\text { Tervo et al. } \\
(2004)[25] \text {, } \\
\text { Finland }\end{array}$ & $\begin{array}{l}\text { aMCI-SD/MD- } \\
\text { combined } \\
\text { Petersen et al. [8] }\end{array}$ & $\begin{array}{l}\text { The criterion has been } \\
\text { omitted }\end{array}$ & The criterion has been omitted & $\begin{array}{l}\text { Memory impairment: test performance } \\
<1.5 \text { standard deviations below the } \\
\text { average (in relation to a healthy sub- } \\
\text { group of the sample) in delayed recall } \\
\text { in the LM from the WMS-R or in the } \\
\text { VR from the WMS; CDR }=0.5 \text {; no } \\
\text { exclusion of subjects with deficits in } \\
\text { cognitive domains other than memory } \\
\text { Preserved general cognitive functioning: } \\
\text { MMSE } \geq 20\end{array}$ \\
\hline
\end{tabular}

(2004) [22],

combined $^{1}$

omitted

\section{Scalment on Katz ADL \\ Brody IADL Scale; no \\ exclusion of subjects (a) with \\ slight ADL impairment but no \\ IADL impairment, (2) with \\ visual, auditory or skeletal \\ muscle disabilities compro- \\ mising ADL, but not cognitive \\ skills, (3) with ADL impaired \\ by comorbid illnesses \\ (2 or more)}

in the lowest 10th percentile of the dis-

tribution of age- and education-adjusted

scores after exclusion of prevalent

dementia at entry; assessed by the total

BRST score (immediate plus delayed

recall)

Preserved general cognitive functioning:

performance on the MMSE not $<1.5$

standard deviations below the mean of

age- and education- adjusted scores after exclusion of subjects with prevalent dementia
Busse et al.

(2003) [30],

LEILA,

Germany

$\begin{array}{ll}\begin{array}{l}\text { aMCI-SD with (1) } \\ \text { and without (2) }\end{array} & \begin{array}{l}\text { (1) Memory complaint; } \\ \text { reported by } \\ \text { criterion of }\end{array} \\ \begin{array}{l}\text { pabjective com- } \\ \text { or both } \\ \text { plaint }\end{array} & \begin{array}{l}\text { (2) The criterion has } \\ \text { Petersen et al. [8] }\end{array} \\ \text { been omitted }\end{array}$

No impairment on SIDAM ADL Scale, impairment due to physical disease was not sufficient for exclusion exclusion of

dementia

DSM-IV criteria for dementia, NINCDSADRDA criteria for $\mathrm{AD}$

\section{DSM-III-R criteria}

for dementia

syndrome,

NINCDS-ADRDA

criteria for possible and probable $\mathrm{AD}$,

ICD-10 criteria for

$\mathrm{VD}$ and OD

$$
\begin{aligned}
& \text { Memory impairment: test performance } \\
& <1 \text { standard deviation below the mean of } \\
& \text { age- and education-specific norms; as- } \\
& \text { sessed by the memory subtest of the } \\
& \text { SIDAM (impairment on the memory } \\
& \text { subtest only and not on subtests relating } \\
& \text { to other cognitive functions) } \\
& \text { Preserved general cognitive functioning: } \\
& \text { test performance not }<1 \text { standard devia- } \\
& \text { tion below the mean of age- and educa- } \\
& \text { tion-specific norms; assessed by the in- } \\
& \text { tellectual abilities' subtest of the SIDAM }
\end{aligned}
$$

\begin{tabular}{|c|c|c|c|c|}
\hline $\begin{array}{l}\text { Larrieu et al. } \\
(2002)[31], \\
\text { PAQUID, } \\
\text { France }\end{array}$ & $\begin{array}{l}\text { aMCI-SD/MD- } \\
\text { combined }^{1} \\
\text { Petersen et al. [8] }\end{array}$ & $\begin{array}{l}\text { Memory complaint; } \\
2 \text { questions on self- } \\
\text { perceived forgetfulness } \\
\text { in daily activities or in } \\
\text { recent events }\end{array}$ & $\begin{array}{l}\text { No impairment on Katz ADL } \\
\text { Scale }\end{array}$ & $\begin{array}{l}\text { Memory impairment: test performance } \\
<1.5 \text { standard deviations of the mean } \\
\text { of age- and education-defined strata; } \\
\text { assessed by the BVRT } \\
\text { Preserved general cognitive functioning: } \\
\text { performance on the MMSE not }<1 \text { stan- } \\
\text { dard deviation below the mean of age- } \\
\text { and education-defined strata in the } \\
\text { cohort after exclusion of prevalent } \\
\text { dementia at entry }\end{array}$ \\
\hline
\end{tabular}

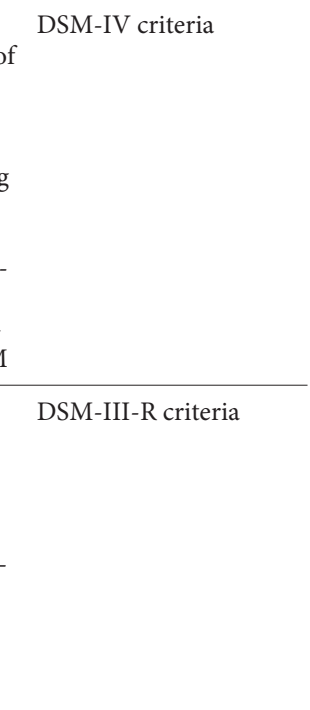

\section{DSM-IV criteria}

$\mathrm{AD}=$ Alzheimer's dementia; $\mathrm{ADL}=$ activities of daily living; $\mathrm{ADRCC}=$ Alzheimer's disease research centers of California; aMCI = amnestic MCI; $\mathrm{BDAE}=$ Boston diagnostic aphasia examination; BFA = blessed functional activities; $\mathrm{BNT}=$ Boston naming test; $\mathrm{BRST}=$ Babcock story recall test; $\mathrm{BVRT}=$ Benton's visual retention test; $\mathrm{CDR}=$ clinical dementia rating; $\mathrm{CF}=$ category fluency; $\mathrm{CI}$ = confidence interval; CSBA = Conselice Study of Brain Ageing; $\mathrm{DFL}=$ disability and functional limitation; DLB = dementia with Lewy bodies; DSM = Diagnostic and Statistical Manual of Mental Disorders; FUPs = followups; IADL = instrumental activities of daily living; ICD = international statisti- cal classification of diseases and related health problems; ILSA = Italian longitudinal study on aging; IQ = intelligence quotient; LEILA = Leipzig longitudinal study of the aged; LF = letter fluency; LM = logical memory; $M D=$ multiple domain; $\mathrm{MDB}=$ mental deterioration battery; $\mathrm{MMSE}=$ mini-mental status examination; naMCI = non-amnestic MCI; NINCDS-ADRDA = National Institute of Neurological and Communicative Disorders and Stroke-Alzheimer's Disease and Related Disorders Association; NINDS-AIREN = National Institute of Neurological and Communication Disorders and Stroke/Association Internationale pour la Recherch et l'Enseignement en Neurosciences; n.s. = not 


\begin{tabular}{lllll}
\hline Sample & $\begin{array}{l}\text { OI (years)/ } \\
\text { No. of } \\
\text { FUPs }\end{array}$ & $\begin{array}{l}\text { Age at } \\
\text { baseline } \\
\text { years }\end{array}$ & $\begin{array}{l}\text { Population } \\
\text { at risk for } \\
\text { incident MCI }\end{array}$ & $\begin{array}{l}\text { Incident } \\
\text { MCI cases } \\
\%(n)\end{array}$ \\
\hline population-based & $\begin{array}{l}\text { mean }=3.3 \\
(\mathrm{SD}=0.7) / 1\end{array}$ & $60-76$ & 747 & $8.8(66)$
\end{tabular}

$\begin{array}{lllll}\text { population-based } & 3.5 / 1 & 65-84 & 1,524 & 7.4^{3}(113)\end{array}$

(stratified for age and gender)

$3.5 / 1$

\begin{tabular}{|c|c|c|c|c|c|}
\hline population-based & $3 / 2$ & $75+$ & $\begin{array}{l}\text { (1) } 900 \\
\text { (2) } 882\end{array}$ & $\begin{array}{l}\text { (1) } 1.7^{3}(15) \\
\text { (2) } 2.4^{3}(21)\end{array}$ & $\begin{array}{l}\text { (1) } 8.5(4.8-14.1) \\
\text { (2) } 12.2(7.6-18.7)\end{array}$ \\
\hline
\end{tabular}

$\begin{array}{lllll}\begin{array}{l}\text { population-based } \\ \text { (institutionalised subjects not } \\ \text { included at baseline) }\end{array} & 5 / 2 & 65+ & 1,265 & 3.2^{3}(40)\end{array}$

(institutionalised subjects not

included at baseline)

specified; OD = other dementia; OI = observation interval; PAQUID = personnes agées QUID; PMT = prose memory test; RDT = Rosen drawing test; SD = single domain; SIDAM = structured interview for diagnosis of dementia of Alzheimer type, multi-infarct dementia and dementia of other aetiology; $\mathrm{SRT}=$ selective reminding test $\mathrm{VD}=$ vascular dementia; $\mathrm{VR}=$ visual reproduction; WAIS = Wechsler adult intelligence scale; WMS = Wechsler memory scale; WMS-R = Wechsler memory scale-revised.

${ }^{1}$ Objective impairments in cognitive domains other than memory were not excluded explicitly and preserved general cognitive functioning also does not ex- clude the possibility of impairments in specific non-amnestic cognitive domains explicitly. Thus, the type of MCI investigated in the study should not be Amnestic MCI Single Domain but rather Amnestic MCI subtypes combined (Single + Multiple Domain).

${ }^{2}$ At least 1 follow-up completed. ${ }^{3}$ Calculated from the study results. ${ }^{4}$ Corrected for mortality during follow-up. ${ }^{5}$ Addition of the incidence rates of naMCI-SD executive, language and visuospatial. 
Table 2. Risk factors for incident MCI

\begin{tabular}{|c|c|c|c|c|}
\hline \multirow[t]{2}{*}{ Study } & \multirow{2}{*}{$\begin{array}{l}\text { MCI subtypes/ } \\
\text { underlying definition of MCI }\end{array}$} & \multirow[t]{2}{*}{ Statistical model } & \multicolumn{2}{|l|}{ Risk factors } \\
\hline & & & significant & not significant \\
\hline $\begin{array}{l}\text { Caracciolo et al. } \\
\text { (2008) [27], Kungsholmen } \\
\text { Project, Sweden }\end{array}$ & $\begin{array}{l}\text { aMCI-SD/MD-combined } \\
\text { Petersen et al. [8] }\end{array}$ & Poisson regression & higher age & gender \\
\hline $\begin{array}{l}\text { Manly et al. } \\
\text { (2008) [28], USA }\end{array}$ & $\begin{array}{l}\text { (1) aMCI-SD/MD-combined } \\
\text { (2) naMCI-SD/MD-combined } \\
\text { (3) any MCI } \\
\text { Petersen [6] } \\
\text { Petersen et al. [7] }\end{array}$ & $\begin{array}{l}\text { Cox proportional } \\
\text { hazards model }\end{array}$ & $\begin{array}{l}\text { (1) aMCI-SD/MD-combined: } \\
\text { - higher age } \\
\text { - history of a diagnosis of hypertension } \\
\text { - history of heart disease (protective) } \\
\text { (2) naMCI-SD/MD-combined: } \\
\text { - lower education ( }<12 \text { years) } \\
\text { (3) any MCI: } \\
\text { - higher age } \\
\text { - ethnicity (black, Hispanic vs. } \\
\text { non-Hispanic white) } \\
\text { - history of a diagnosis of hyper- } \\
\text { tension }\end{array}$ & $\begin{array}{l}\text { (1) aMCI-SD/MD-combined: } \\
\text { - gender } \\
\text { - education } \\
\text { - ethnicity (black, Hispanic vs. } \\
\text { non-Hispanic white) } \\
\text { - cohort } \\
\text { - diabetes mellitus } \\
\text { - stroke } \\
\text { - psychiatric illness } \\
\text { (2) naMCI-SD/MD-combined: } \\
\text { - age } \\
\text { - gender } \\
\text { - ethnicity (black, Hispanic vs. } \\
\text { non-Hispanic white) } \\
\text { - cohort } \\
\text { - history of heart disease } \\
\text { - history of a diagnosis of } \\
\text { - hypertension } \\
\text { - diabetes mellitus } \\
\text { - stroke } \\
\text { - psychiatric illness } \\
\text { (3) any MCI: } \\
\text { - gender } \\
\text { - education } \\
\text { - cohort } \\
\text { - history of heart disease } \\
\text { - diabetes mellitus } \\
\text { - stroke } \\
\text { - psychiatric illness } \\
\text { - apoE } \varepsilon 4 \text { allele }{ }^{1}\end{array}$ \\
\hline $\begin{array}{l}\text { Verghese et al. } \\
\text { (2006) [29], Bronx } \\
\text { Aging Study, USA }\end{array}$ & $\begin{array}{l}\text { aMCI-SD/MD-combined } \\
\text { Petersen et al. [8] }\end{array}$ & $\begin{array}{l}\text { Cox proportional } \\
\text { hazards model }\end{array}$ & - cognitive activity (protective) & - physical activity \\
\hline $\begin{array}{l}\text { Tervo et al. } \\
\text { (2004) [25], Finland }\end{array}$ & $\begin{array}{l}\text { aMCI-SD/MD-combined } \\
\text { Petersen et al. [8] }\end{array}$ & $\begin{array}{l}\text { Multiple logistic } \\
\text { regression analysis }\end{array}$ & $\begin{array}{l}\text { - higher age } \\
\text { - higher education (protective) } \\
\text { - apoE } \varepsilon 4 \text { allele } \\
\text { - medicated hypertension }\end{array}$ & $\begin{array}{l}\text { - gender } \\
\text { - cardiovascular diseases } \\
\quad \text { (significant risk factor when } \\
\text { analysed separately) } \\
\text { - cerebrovascular diseases } \\
\text { - diabetes mellitus } \\
\text { - elevated blood pressure }\end{array}$ \\
\hline $\begin{array}{l}\text { Solfrizzi et al. } \\
\text { (2004) [22], ILSA, Italy }\end{array}$ & $\begin{array}{l}\text { aMCI-SD/MD-combined } \\
\text { Petersen et al. [8] }\end{array}$ & Poisson regression & $\begin{array}{l}\text { - higher age } \\
\text { - higher education (protective) }\end{array}$ & $\begin{array}{l}\text { - cigarette pack-years } \\
\text { - coronary artery disease } \\
\text { - hypertension } \\
\text { - higher levels of serum total } \\
\text { cholesterol (borderline non- } \\
\text { significant trend for a protec- } \\
\text { tive effect) }\end{array}$ \\
\hline
\end{tabular}

aMCI = Amnestic MCI; ILSA = Italian Longitudinal Study on Aging; MD = multiple domain; naMCI = non-amnestic MCI; SD = single domain .

${ }^{1}$ Among a subsample with apoE data $(n=1,472)$ higher age and hypertension remained risk factors, but ethnicity and apoE $\varepsilon 4$ allele failed to be significant risk factors. 
Fig. 1. Results of the systematic literature search.

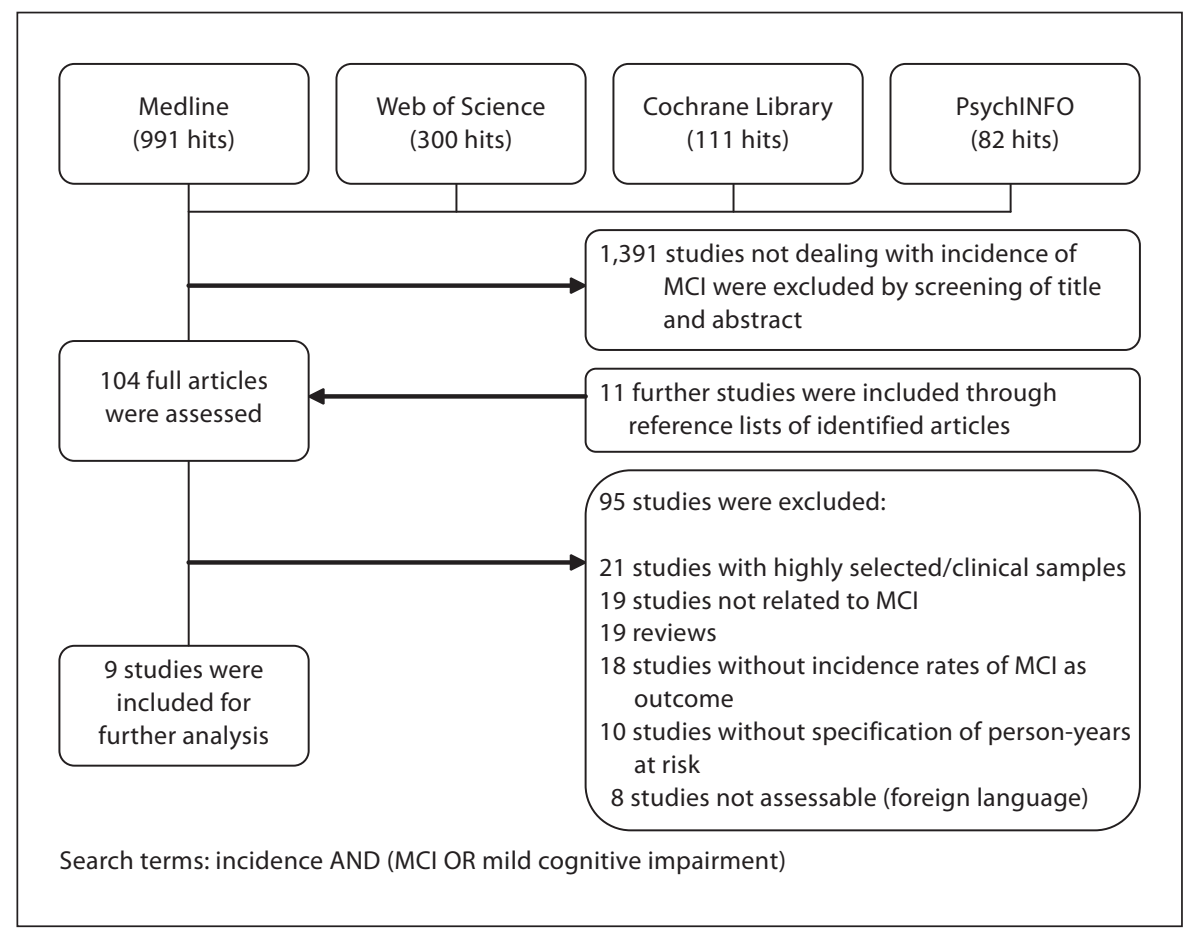

the MCI criteria. For example, objective memory impairment was defined either as test performance $<1.0$ standard deviations or as test performance $<1.5$ standard deviations below the mean of a reference group or as test performance in the lowest 10th percentile in relation to a reference group. Moreover, test norms were mostly corrected for age and education but also for ethnicity and sex.

\section{Incidence Rates of MCI}

MCI was developed in 1.7-22.6\% of the study populations at risk. Altogether, the incidence rates of MCI varied between 8.5 and 76.8 per 1,000 person-years.

With regard to amnestic MCI single domain, incidence rates of 8.5 [30], 12.2 (criterion of cognitive complaint omitted) [30] and 14 [28] per 1,000 person-years were found. Concerning amnestic MCI multiple domain, non-amnestic MCI single domain and non-amnestic MCI multiple domain, Manly et al. [28] reported incidence rates of 9,23 and 5 per 1,000 person-years. The incidence rates of amnestic MCI subtypes combined (single + multiple domain) ranged between 9.9 and 40.6 per 1,000 person-years $[21,22,26-29,31]$, whereas the highest rates (25.9 and 40.6 per 1,000 person-years) were found in studies omitting the criterion of cognitive complaint [21, 25] and the lowest ones (9.9 and 13.2 per 1,000 person- years) in trials including the criterion $[26,31]$. Regarding non-amnestic MCI subtypes combined, incidence rates of 28 [28] and 36.3 (criterion of cognitive complaint omitted) [21] per 1,000 person-years have been reported.

Information on the incidence of any MCI (all 4 subtypes combined) was given in 2 studies; Manly et al. [28] reported an incidence of MCI of 51 per 1,000 personyears and Ravaglia et al. [21] of 76.8 per 1,000 personyears omitting the criterion of cognitive complaint.

\section{Risk Factors for Incidence of MCI}

Possible risk factors for the incidence of MCI were analysed in 5 of the 9 studies using multivariate statistical methods like Poisson regression, multiple logistic regression or Cox proportional hazards models (table 2). All 5 studies referred to amnestic MCI subtypes combined (single + multiple domain). Manly et al. [28] additionally referred to non-amnestic MCI subtypes combined and any MCI.

Regarding amnestic MCI subtypes, a significant impact of age on the incidence was found in all 4 studies that analysed age as a possible risk factor [22, 25, 27, 28]. By contrast, a significant impact of gender on the incidence of amnestic MCI subtypes could not be identified. A higher level of education was found to be a rather protective factor for incident amnestic MCI subtypes in 2 stud- 
ies [22, 25] but not in all [28]. Ethnicity failed to have a significant effect. The impact of higher cognitive activity on the incidence of amnestic MCI subtypes was analysed in 1 study and could be identified as a protective factor [29]. The influence of vascular factors and diseases on the incidence of amnestic MCI subtypes was analysed in 3 studies [22, 25, 28]. Hypertension could be identified as a risk factor in 2 of the 3 trials $[25,28]$. History of heart disease was analysed in 1 study [28] and was found to be a rather protective factor. Cardiovascular diseases in general (when analysed multivariately [25]), however, failed to be significant risk factors; this was also true for coronary artery disease, serum total cholesterol [22], cerebrovascular diseases [25], stroke [28], diabetes mellitus [25, 28], cigarette pack-years [22] and psychiatric illness [28]. ApoE $\varepsilon 4$ allele - analysed in 1 study [25] - was found to be a risk factor for the incidence of the amnestic MCI subtypes.

Regarding incident non-amnestic MCI subtypes, only lower education ( $<12$ years) was found to be a significant risk factor [28]. With respect to the incidence of any MCI - according to the result for amnestic MCI subtypes - higher age and history of a diagnosis of hypertension were found to be significant risk factors. Ethnicity (black, Hispanic vs. non-Hispanic white) was only found to be a risk factor for MCI in an overall sample [28]. No impact on the incidence of any MCI was found for gender, education, history of heart disease, diabetes mellitus, stroke, psychiatric illness and the apoE $\varepsilon 4$ allele [28].

\section{Discussion}

\section{Incidence Rates in Consideration of Study}

Characteristics and Identified Risk Factors

Our review shows that findings on the incidence rates of MCI vary widely particularly with regard to the amnestic MCI subtypes. These variations in the incidence rates generally might be affected by differences in the study characteristics like the age of the sample or in the criteria used for MCI and their operationalisation. With regard to the age of the study samples, being older was found to be strongly associated with a higher risk or a higher incidence rate of MCI. Concerning the impact of MCI criteria, 4 of the 9 studies reported incidence rates for MCI concepts omitting the criteria of cognitive complaint. If MCI is diagnosed including an obligate criterion of cognitive complaint, the incidence rates should be lower because a high percentage of objectively cognitively impaired subjects does not complain about their cogni- tion [20]. Regarding the study by Busse et al. [30], for example, the inclusion of memory complaint lowered the incidence of amnestic MCI single domain from 12.2 to 8.5 per 1,000 person-years (table 1 ). Whether a subjective cognitive complaint should be mandatory for a diagnosis of MCI, raises a controversial issue [32-34]. For example, objectively cognitively impaired subjects who do not complain about their cognition would not be classified as cognitively mildly impaired according to MCI criteria including a mandatory criterion of subjective cognitive complaint. Thus, they would be excluded a priori from a possible risk population for progression to dementia. Moreover, many cross-sectional studies have shown that subjective memory impairments, for example, are rather associated with factors like depression or anxiety $[35,36]$ than with objective test performance. A predictive value of subjective cognitive impairments for future cognitive decline, however, was found in many longitudinal studies with larger representative population samples [34, 37]. Additionally, subjective impairments are often the only indication of incipient cognitive deterioration in highly educated persons [38]. The inclusion of subjective cognitive complaints in a definition of MCI can be expedient for an early detection of dementia, yet it requires a standardised and validated set of criteria of these complaints according to the set proposed by Abdulrab and Heun [39] - for subjective memory impairments, for example.

A 'gold standard' is not only necessary for the operationalisation of the subjective cognitive complaints, it is also required for the operationalisation of the remaining criteria of MCI. With regard to the criterion of objective cognitive impairment, for example, there are significant differences in the applied cognitive tests and test norms used for operationalisation. As an example, if objective cognitive impairment is defined as a test performance $<1.5$ standard deviations below the mean of a reference group, the incidence of MCI will - only for statistical reasons - be lower than if the objective cognitive impairment were defined as a test performance $<1.0$ standard deviations below the mean of a reference group. Moreover, studies that use short cognitive test batteries may miss a significant number of cases due to a lack of sensitivity to detect the less severe MCI syndromes, which would produce an underestimation of MCI incidence.

Possible risk factors for incident MCI were analysed only to a limited extent in most of the included studies. However, a higher risk of incident MCI was particularly found for higher age, lower education and hypertension, but not for gender. An increase in the incidence of MCI with age is not unexpected, as MCI represents a pre-de- 
mentia stage in many cases [12-14], and the incidence of dementia itself also increases with age $[40,41]$. The findings regarding gender and education are consistent with those from many prevalence studies showing a lack of association between gender and prevalence of MCI and a positive relationship between higher education and lower prevalence of MCI [22, 23, 42-44]. A high level of education was also found to be associated with a decreased risk for incident Alzheimer's disease (AD) yet with a faster cognitive decline in clinically manifest AD [45]. These findings have been explained by the cognitive reserve theory [45-47]: a decreased risk for incident AD can be found in persons with higher education because they have more cognitive reserve than persons with low education, enabling them to cope with progressive AD pathology longer before it is expressed clinically. However, if $\mathrm{AD}$ becomes clinically manifest in highly educated persons, the $\mathrm{AD}$ pathology should be more advanced than in less educated persons and thus associated with a faster cognitive decline. As shown by Scarmeas et al. [45], findings on an advanced $\mathrm{AD}$ pathology in highly educated persons have been supported through some imaging studies.

The apoE $\varepsilon 4$ allele represents a proven genetic risk factor for $\mathrm{AD}[48,49]$. In the study by Tervo et al. [25], the apoE $\varepsilon 4$ allele was also identified as a risk factor for incident MCI. The association between apoE $\varepsilon 4$ genotype and MCI needs to be seen in a nuanced light, since a significant impact of the apoE $\varepsilon 4$ genotype on the incidence of MCI could not be found in all studies [28]. There is evidence that apoE $\varepsilon 4$ is generally associated with memory impairment, and not solely in subjects with $\mathrm{AD}$ [50]. Conversely, there is also evidence that the effect of apoE $\varepsilon 4$ on memory definitely depends on an underlying $\mathrm{AD}$ pathology, yet only in higher age [51]. Thus, further studies are required in order to better understand the association between apoE $\varepsilon 4$ and developing MCI and $\mathrm{AD}$.

Unlike non-modifiable genetic risk factors such as apoE $\varepsilon 4$, vascular risk factors and diseases provide an opportunity for preventive approaches (sport, avoidance of smoking and excessive drinking, etc.) and thus an opportunity to influence the development of MCI and dementia. Regarding the included incident studies, hypertension was particularly found to be a significant risk factor for future MCI. The mechanisms underlying the association between hypertension and future MCI, however, are not completely clarified. Explanations like increased frequency of neurofibrillary tangles, increased brain atrophy, higher risk of white matter hyperintensities and lacunar brain infarcts or dysfunction of the blood-brain barrier in hypertensive subjects have been outlined by Reitz et al. [52]. Regarding cross-sectional findings, a significant association with MCI was also found for vascular diseases like transient ischaemic attack [38], stroke/ MRI-identified infarct/cerebral haemorrhage [38, 43, 53], atrial fibrillation [43] or peripheral arterial obstructive disease [20].

Most of these diseases, however, were not analysed as separate risk factors in the incident studies. Stroke was considered separately but not found to be a significant risk factor for incident MCI [28]. The lack of association with future MCI might be due to the fact that stroke usually causes cognitive deficits immediately. Subjects with stroke and coincidental cognitive deficits (MCI), however, had to be excluded in incident MCI studies at baseline. By contrast, subjects with stroke and without cognitive deficits at the baseline date of an incident study might suffer from less severe strokes. Moreover, the stroke might have appeared earlier in life, meaning cognitive deficits might already have improved by the beginning of the incident study.

\section{Implications for Research}

This review on the incidence of MCI may contribute to estimating the need for secondary prevention of incipient cognitive deterioration up to dementia and for the development of new preventive and curative approaches. However, the compiled findings also reveal grey areas where continuative research efforts are required.

Firstly, as mentioned above, possible risk factors for incident MCI were analysed only to a limited extent in most of the included studies. At present, neuroimaging measures and biomarkers (e.g. hippocampal atrophy, reduced hippocampal metabolism, increased tau protein in cerebrospinal fluid) become more and more important with regard to an identification of the subjects (with MCI) who are at high risk of developing dementia [16, 54-56]. Of course, it is not possible to analyse all possible risk factors for MCI in large community- and populationbased studies exhaustively. Nevertheless, neuroimaging measures and biomarkers should be taken into account increasingly in future research.

Secondly, the MCI concept in general has to be empirically validated further. As shown by Busse et al. [13], the course of MCI is heterogeneous. A substantial number of subjects with MCI progresses to dementia, but there are also patients who improve to 'normal' after MCI diagnosis, and there are subjects with a stable or unstable course of MCI over several observation points in time. Thus, future studies on the incidence of MCI should in- 
clude a substantial number of follow-ups with short time intervals in between to examine the course of MCI more exactly. Furthermore, an agreement concerning the criteria used for MCI and the operationalisation of these criteria is required (e.g. the use of a consistent cut-off in cognitive tests for the definition of objective cognitive impairment) to ensure the comparability of different epidemiological and clinical findings on MCI.

Finally, a diagnosis of MCI is clinically useful for the identification of a high-risk population for the development of dementia. With regard to the substantial number of subjects with MCI who do not progress to dementia, an MCI diagnosis alone cannot, however, be equated with a pre-dementia stage of a neurodegenerative disorder [11] and therefore does not allow the implementation of treatment like medication. In order to define an MCI concept allowing these treatments, Förstl et al. [54, 55] have supplemented the MCI diagnosis with predictors of a rapid cognitive decline (older age, vascular risk factors, neurological symptoms, apoE $\varepsilon 4$ genotype, etc.). Advancement and validation of such an MCI plus [54, 55] concept should be the utmost concern of future research on MCI.

\section{Acknowledgment}

The review was published in affiliation with the Leipzig Interdisciplinary Research Cluster of Genetic Factors, Clinical Phenotypes and Environment, which is financed by means of the European Union (European Regional Development Fund) and the Free State of Saxony.

\section{References}

1 Ferri CP, Prince M, Brayne C, Brodaty H, Fratiglioni L, Ganguli M, Hall K, Hasegawa K, Hendrie H, Huang Y, Jorm A, Mathers C, Menezes PR, Rimmer E, Scazufca M, Alzheimer's Disease International: Global prevalence of dementia: a Delphi consensus study. Lancet 2005;366:2112-2117.

$\checkmark 2$ Crook T, Bartus RT, Ferris SH, Whitehouse P, Cohen GD, Gershon S: Age-associated memory impairment: proposed diagnostic criteria and measures of clinical change - report of a National Institute of Mental Health Work Group. Dev Neuropsychol 1986;2:261-276.

$>3$ Levy R, Working Party of the International Psychogeriatric Association in collaboration with the World Health Organization: Agingassociated cognitive decline. Int Psychogeriatr 1994;6:63-68.

4 Ebly EM, Parhad IM, Hogan DB, Fung TS: Prevalence and types of dementia in the very old: results from the Canadian Study of Health and Aging. Neurology 1994;44:15931600 .

$\checkmark 5$ Ebly EM, Hogan DB, Parhad IM: Cognitive impairment in the nondemented elderly: results from the Canadian Study of Health and Aging. Arch Neurol 1995;52:612-619.

6 Petersen RC: Mild cognitive impairment as a diagnostic entity. J Intern Med 2004;256: 183-194.

$\checkmark 7$ Petersen RC, Doody R, Kurz A, Mohs RC, Morris JC, Rabins PV, Ritchie K, Rossor M, Thal L, Winblad B: Current concepts in mild cognitive impairment. Arch Neurol 2001;58: 1985-1992.

8 Petersen RC, Smith GE, Waring SC, Ivnik RJ, Tangalos EG, Kokmen E: Mild cognitive impairment: clinical characterization and outcome. Arch Neurol 1999;56:303-308. $\checkmark 9$ Winblad B, Palmer K, Kivipelto M, Jelic V, Fratiglioni L, Wahlund LO, Nordberg A, Backman L, Albert M, Almkvist O, Arai H, Basun H, Blennow K, de Leon M, DeCarli C, Erkinjuntti T, Giacobini E, Graff C, Hardy J, Jack C, Jorm A, Ritchie K, van Duijn C, Visser P, Petersen RC: Mild cognitive impairment - beyond controversies, towards a consensus: report of the International Working Group on Mild Cognitive Impairment. J Intern Med 2004;256:240-246.

10 Petersen RC, Knopman DS: MCI is a clinically useful concept. Int Psychogeriatr 2006; 18:394-402; discussion 409-414.

11 Visser PJ, Brodaty H: MCI is not a clinically useful concept. Int Psychogeriatr 2006;18: 402-409; discussion 409-414.

-12 Amieva H, Letenneur L, Dartigues JF, Rouch-Leroyer I, Sourgen C, D’Alchée-Birée F, Dib M, Barberger-Gateau P, Orgogozo JM, Fabrigoule C: Annual rate and predictors of conversion to dementia in subjects presenting mild cognitive impairment criteria defined according to a population-based study. Dement Geriatr Cogn Disord 2004;18:87-93.

13 Busse A, Hensel A, Gühne U, Angermeyer MC, Riedel-Heller SG: Mild cognitive impairment: long-term course of four clinical subtypes. Neurology 2006;67:2176-2185.

14 Luis CA, Barker WW, Loewenstein DA, Crum TA, Rogaeva E, Kawarai T, GeorgeHyslop P, Duara R: Conversion to dementia among two groups with cognitive impairment. Dement Geriatr Cogn Disord 2004;18: 307-313.

15 Yaffe K, Petersen RC, Lindquist K, Kramer J: Subtype of mild cognitive impairment and progression to dementia and death. Dement Geriatr Cogn Disord 2006;22:312-319.
16 Modrego PJ: Predictors of conversion to dementia of probable Alzheimer type in patients with mild cognitive impairment. Curr Alzheimer Res 2006;3:161-170.

17 Grundman M, Petersen RC, Ferris SH, Thomas RG, Aisen PS, Bennett DA, Foster NL, Jack CR Jr, Galasko DR, Doody R, Kaye J, Sano M, Mohs R, Gauthier S, Kim HT, Jin S, Schultz AN, Schafer K, Mulnard R, van Dyck CH, Mintzer J, Zamrini EY, CahnWeiner D, Thal LJ: Mild cognitive impairment can be distinguished from Alzheimer disease and normal aging for clinical trials. Arch Neurol 2004;61:59-66.

18 Artero S, Petersen R, Touchon J, Ritchi K: Revised criteria for mild cognitive impairment: validation within a longitudinal population study. Dement Geriatr Cogn Disord 2006;22:465-470.

19 Kumar R, Dear KB, Christensen H, Ilschner S, Jorm AF, Meslin C, Rosenman SJ, Sachdev PS: Prevalence of mild cognitive impairment in 60- to 64-year-old community-dwelling individuals: the Personality and Total Health through Life 60+ Study. Dement Geriatr Cogn Disord 2005; 19:67-74.

-20 Luck T, Riedel-Heller SG, Kaduszkiewicz H, Bickel H, Jessen F, Pentzek M, Wiese B, Koelsch $\mathrm{H}$, van den Bussche $\mathrm{H}$, Abholz $\mathrm{HH}$, Moesch E, Gorfer S, Angermeyer MC, Maier W, Weyerer S, AgeCoDe Group: Mild cognitive impairment in general practice: age-specific prevalence and correlate results from the German study on ageing, cognition and dementia in primary care patients (AgeCoDe). Dement Geriatr Cogn Disord 2007; 24:307-316. 
-21 Ravaglia G, Forti P, Montesi F, Lucicesare A, Pisacane N, Rietti E, Dalmonte E, Bianchin M, Mecocci P: Mild cognitive impairment: epidemiology and dementia risk in an elderly Italian population. J Am Geriatr Soc 2008; 56:51-58.

22 Solfrizzi V, Panza F, Colacicco AM, D’Introno A, Capurso C, Torres F, Grigoletto F, Maggi S, Del Parigi A, Reiman EM, Caselli RJ, Scafato E, Farchi G, Capurso A, Italian Longitudinal Study on Aging Working Group: Vascular risk factors, incidence of $\mathrm{MCI}$, and rates of progression to dementia. Neurology 2004;63:1882-1891.

-23 Tognoni G, Ceravolo R, Nucciarone B, Bianchi F, Dell'Agnello G, Ghicopulos I, Siciliano G, Murri L: From mild cognitive impairment to dementia: a prevalence study in the district of Tuscany, Italy. Acta Neurol Scand 2005; 112:65-71.

24 Petersen RC, Smith GE, Ivnik RJ, Tangalos EG, Schaid DJ, Thibodeau SN, Kokmen E, Waring SC, Kurland LT: Apolipoprotein E status as a predictor of the development of Alzheimer's disease in memory-impaired individuals. JAMA 1995;273:1274-1278.

-25 Tervo S, Kivipelto M, Hänninen T, Vanhanen M, Hallikainen M, Mannermaa A, Soininen $\mathrm{H}$ : Incidence and risk factors for mild cognitive impairment: a populationbased three-year follow-up study of cognitively healthy elderly subjects. Dement Geriatr Cogn Disord 2004;17:196-203.

-26 Chaves ML, Camozzato AL, Godinho C, Piazenski I, Kaye J: Incidence of mild cognitive impairment and Alzheimer disease in southern Brazil. J Geriatr Psychiatry Neurol 2009;22:181-187.

-27 Caracciolo B, Palmer K, Monastero R, Winblad B, Bäckman L, Fratiglioni L: Occurrence of cognitive impairment and dementia in the community: a 9-year-long prospective study. Neurology 2008;70:1778-1785.

28 Manly JJ, Tang MX, Schupf N, Stern Y, Vonsattel JPG, Mayeux R: Frequency and course of mild cognitive impairment in a multiethnic community. Ann Neurol 2008;63:494-506.

29 Verghese J, LeValley A, Derby C, Kuslansky G, Katz M, Hall C, Buschke H, Lipton RB: Leisure activities and the risk of amnestic mild cognitive impairment in the elderly. Neurology 2006;66:821-827.

-30 Busse A, Bischkopf J, Riedel-Heller SG, Angermeyer MC: Mild cognitive impairment: prevalence and incidence according to different diagnostic criteria - results of the Leipzig Longitudinal Study of the Aged (LEILA75+). Br J Psychiatry 2003;182:449-454.

-31 Larrieu S, Letenneur L, Orgogozo JM, Fabrigoule C, Amieva H, Le Carret N, BarbergerGateau P, Dartigues JF: Incidence and outcome of mild cognitive impairment in a population-based prospective cohort. Neurology 2002;59:1594-1595.

>32 Jungwirth S, Fischer P, Weissgram S, Kirchmeyr W, Bauer P, Tragl KH: Subjective memory complaints and objective memory impairment in the Vienna-Transdanube Aging Community. J Am Geriatr Soc 2004;52:263-268.
33 Purser JL, Fillenbaum GG, Wallace RB: Memory complaint is not necessary for diagnosis of mild cognitive impairment and does not predict 10-year trajectories of functional disability, word recall, or short portable mental status questionnaire limitations. J Am Geriatr Soc 2006;54:335-338.

34 Riedel-Heller SG, Schork A, Matschinger H, Angermeyer MC: Subjective memory loss - a sign of cognitive impairment in the elderly? An overview of the status of research (in German). Z Gerontol Geriatr 2000;33:9-16.

-35 Jorm AF, Butterworth P, Anstey KJ, Christensen H, Easteal S, Maller J, Mather KA, Turakulov RI, Wen W, Sachdev P: Memory complaints in a community sample aged 60 64 years: associations with cognitive functioning, psychiatric symptoms, medical conditions, APOE genotype, hippocampus and amygdala volumes, and white-matter hyperintensities. Psychol Med 2004;34:1495-1506.

36 Reid LM, Maclullich AM: Subjective memory complaints and cognitive impairment in older people. Dement Geriatr Cogn Disord 2006;22:471-485.

>37 Dufouil C, Fuhrer R, Alpérovitch A: Subjective cognitive complaints and cognitive decline: consequence or predictor? The epidemiology of vascular aging study. J Am Geriatr Soc 2005;53:616-621.

38 Bickel H, Mösch E, Seigerschmidt E, Siemen M, Förstl H: Prevalence and persistence of mild cognitive impairment among elderly patients in general hospitals. Dement Geriatr Cogn Disord 2006;21:242-250.

39 Abdulrab K, Heun R: Subjective memory impairment: a review of its definitions indicates the need for a comprehensive set of standardised and validated criteria. Eur Psychiatry 2008;23:321-330.

40 Jorm AF, Jolley D: The incidence of dementia: a meta-analysis. Neurology 1998;51:728733.

41 Riedel-Heller SG, Busse A, Aurich C, Matschinger $\mathrm{H}$, Angermeyer MC: Incidence of dementia according to DSM-III-R and ICD-10. 2. Results of the Leipzig Longitudinal Study of the Aged (LEILA75+). Br J Psychiatry 2001;179:255-260.

42 Ganguli M, Dodge HH, Shen C, DeKosky ST: Mild cognitive impairment, amnestic type: an epidemiologic study. Neurology 2004;63: 115-121.

43 Hänninen T, Hallikainen M, Tuomainen S, Vanhanen M, Soininen H: Prevalence of mild cognitive impairment: a populationbased study in the elderly subjects. Acta Neurol Scand 2002;106:148-154.

44 Panza F, D’Introno A, Colacicco AM, Capurso C, Del Parigi A, Caselli RJ, Pilotto A, Argentieri G, Scapicchio PL, Scafato E, Capurso A, Solfrizzi V: Current epidemiology of mild cognitive impairment and other predementia syndromes. Am J Geriatr Psychiatry 2005;13:633-644.
45 Scarmeas N, Albert SM, Manly JJ, Stern Y: Education and rates of cognitive decline in incident Alzheimer's disease. J Neurol Neurosurg Psychiatry 2006;77:308-316.

46 Scarmeas N, Stern Y: Cognitive reserve: implications for diagnosis and prevention of Alzheimer's disease. Curr Neurol Neurosci Rep 2004;4:374-380.

47 Stern Y: What is cognitive reserve? Theory and research application of the reserve concept. J Int Neuropsychol Soc 2002;8:448460.

48 Farrer LA, Cupples LA, Haines LL, Hyman B, Kukull WA, Mayeux R, Myers RH, Pericak-Vance MA, Risch N, van Duijn CM, APOE and Alzheimer Disease Meta Analysis Consortium: Effects of age, sex, and ethnicity on the association between apolipoprotein E genotype and Alzheimer disease: a meta-analysis. JAMA 1997;278:1349-1356.

49 Rogaeva E, Kawarai T, George-Hyslop PS: Genetic complexity of Alzheimer's disease: successes and challenges. J Alzheimer Dis 2006;9:381-387.

50 Small BJ, Rosnick CB, Fratiglioni L, Bäckman L: Apolipoprotein E and cognitive performance: a meta-analysis. Psychol Aging 2004;19:592-600.

51 Ramakers IH, Visser PJ, Aalten P, Bekers O, Sleegers K, van Broeckhoven CL, Jolles J, Verhey FR: The association between APOE genotype and memory dysfunction in subjects with mild cognitive impairment is related to age and Alzheimer pathology. Dement Geriatr Cogn Disord 2008;26:101108.

52 Reitz C, Tang MX, Manly J, Mayeux R, Luchsinger JA: Hypertension and the risk of mild cognitive impairment. Arch Neurol 2007;64:1734-1740.

53 Lopez OL, Jagust WJ, Dulberg C, Becker JT, DeKosky ST, Fitzpatrick A, Breitner J, Lyketsos C, Jones B, Kawas C, Carlson M, Kuller LH: Risk factors for mild cognitive impairment in the Cardiovascular Health Study Cognition Study. Arch Neurol 2003;60: 1394-1399.

54 Förstl H, Bickel H, Frölich L, Gertz HJ, Gutzmann H, Hörr R, Pantel J, Schmidt R, Schönknecht P, Ulm K, Werheid K: MCIplus: mild cognitive impairment with rapid progression. I. Prevention and therapy (in German). Dtsch Med Wochenschr 2009;134: 39-44.

55 Förstl H, Werheid K, Ulm K, Schönknecht P, Schmidt R, Pantel J, Hörr R, Gutzmann H, Gertz HJ, Frölich L, Bickel H: MCI-plus: mild cognitive impairment with rapid progression. II. Biomarkers and research methods (in German). Dtsch Med Wochenschr 2009;134:88-91.

56 Wolf H, Jelic V, Gertz HJ, Nordberg A, Julin P, Wahlund LO: A critical discussion of the role of neuroimaging in mild cognitive impairment. Acta Neurol Scand Suppl 2003; 179:52-76. 